\title{
A checklist of medically important flies (Order: Diptera) in the central region of Thailand
}

\author{
TANAWAT CHAIPHONGPACHARA ${ }^{1, \vartheta}$, SEDTHAPONG LAOJUN ${ }^{2}$, NITIWOOT JONGVISUTTISAN ${ }^{3}$, \\ PATCHARAPRON TUBSAMUT ${ }^{3}$, APICHAYA DASOM ${ }^{3}$ \\ ${ }^{1}$ College of Allied Health Science, Suan Sunandha Rajabhat University, Samut Songkhram 75000, Thailand. Tel./fax. $+66-835-865775$, \\ • email: tanawat.ch@ssru.ac.th \\ ${ }^{2}$ Program of Public Health, College of Allied Health Sciences, Suan Sunandha Rajabhat University, Samut Songkhram 75000, Thailand. \\ ${ }^{3}$ Program of Health Science, College of Allied Health Sciences, Suan Sunandha Rajabhat University, Samut Songkhram 75000, \\ Thailand
}

Manuscript received: 28 September 2018. Revision accepted: 28 October 2018.

\begin{abstract}
Chaiphongpachara T, Laojun S, Jongvisuttisan N, Tubsamut P, Dasom A. 2018. A checklist of medically important flies (Order: Diptera) in the central region of Thailand. Biodiversitas 19: 2134-2139. This study surveyed species of medically important flies in the central region of Thailand including Samut Songkram (coastal area representative), Bangkok (urban area representative), Phranakhon Si Ayutthaya (Lower alluvial area representative), Nakhon Sawan (upper alluvial area representative) and Sukhothai (mountainous area representative). This was done through a division of the central region into 5 areas, according to the landscape, including the coastal area, urban area, upper alluvial area, lower alluvial area and mountainous area. Flies were collected using insect nets and fly traps during July 2018. A total was 3872 adult flies, belonging to 4 subfamilies and 6 genera within 9 species were captured. The highest numbers of flies were found in the mountainous area, followed by coastal areas, upper alluvial area, urban area and lower alluvial area, respectively. All the study areas were within the central region of Thailand. The Chrysomya megacephala was the predominant species, with a total of 2953 adult flies captured. This was followed by the Musca domestica $(\mathrm{n}=563)$, Achoetandrus rufifacies $(\mathrm{n}=177)$ and Sacrophaga spp. $(\mathrm{n}=137)$, respectively. The four species of flies collected in this study were Lucilia cuprina $(\mathrm{n}$ $=28)$, A. villeneuvi $(\mathrm{n}=2)$, C. nigripes $(\mathrm{n}=2)$ and Hemipygiopsis ligurriens $(\mathrm{n}=2)$. The results of this study showed the distribution of flies, which is important information for diarrhoea vector control.
\end{abstract}

Keywords: Checklist, Diptera, flies, Thailand

\section{INTRODUCTION}

Flies (Order: Diptera) are considered to be one of the medically important insects to humans. Globally, there are more than 120,000 species of flies (Service 2008). Flies can be mechanical vectors of enteric pathogens (Sukontason et al. 2007) including medically important bacteria, such as Escherichia coli, Staphylococcus coagulase, Listeria monocytogenes, Vibrio cholerae, Salmonella spp., Shigella spp. and Campylobacter spp. (Barreiro et al. 2013; Nwe Oo et al. 1989; Khalil et al. 1994). They are also a major vector of important parasites, including protozoa, such as Entamoeba histolytica, Balantidium coli, Giardia lamblia, Cryptosporidium parvum (Graczyk et al. 2005; El-Sherbini and Gneidy 2012) and intestinal nematodes or soil-transmitted helminths (STH), such as Ascaris lumbricoides, Trichuris trichiura, hookworm and Taenia spp. (Nyarango et al. 2008; Fetene and Worku 2009). There have also been reports that illustrate the ability of flies to carry the viruses and fungi to humans (Junqueira et al. 2017; Phoku et al. 2014). While, it is usually adult flies that are disease vectors, the larval stages of some species can also cause myiasis (Francesconi and Lupi, 2012; Akbarzadeh et al., 2018) Myiasis is the invasion of fly larvae, especially blowflies (Diptera: Calliphoridae) into organs and tissues of humans or other vertebrate animals (Service 2008), feeding on the living or dead tissue and liquid body substances (Francesconi and Lupi 2012). In addition, the larvae of some fly species are also useful in forensic investigations (Joseph et al. 2011).

In Thailand, there are 3 groups of medically important flies. These include the blowfly, house fly and flesh fly. The main problem with regards to these flies is that they are the major cause of diarrhea in Thailand. The annual epidemiological surveillance report of Thailand in 2017 showed that the morbidity rate was 1571.83 per 100,000 population, which amounted to a total of $1,038,349$ cases (Ministry of Public Health 2017). However, this issue could be resolved through vector control actions, especially for the flies. They also affect tourism in Thailand, as the problem is viewed as a health hazard and portrays a bad image of the country's sanitation (Greenberg 1971).

The central region of Thailand covers the Chao Phraya River basin and is a region that is environmentally diverse, as it includes coastal areas, urban areas, river basins, mountainous areas, and forested areas. Consequently, these environmental differences affect the variety and density of animals (Milligan et al. 2009). The species of flies specific to the environment, such as Achoetandrus rufifacies, are found in the plains and at a very high altitude of $2100 \mathrm{~m}$ above sea level (Tumrasvin and Shinonaga 1978). Each 
species of flies has different abilities how they carry pathogens. For instance, the Chrysomya megacephala plays a more important role than the Musca domestica due to its larger size. As such, parasites have a greater chance of pathogens attaching to them (Maipanich et al. 2010). In addition, each species of flies exhibits different behavior, including those involving its habitat, food, and flight (Service 2008). Currently, there is little information regarding the abundance and distribution of medically important flies in the central region of Thailand. Furthermore, it is very difficult to control flies if research lacks the basics of biological, ecological and abundance information pertaining to them.

Therefore, for this study, we surveyed medically important flies in the central region of Thailand. This information will be useful for planning a highly efficient surveillance and control of fly population, eventually leading to a reduction of diarrhea cases within these probable vectors.

\section{MATERIALS AND METHODS}

\section{Collection sites}

In this study, we grouped the provinces in the central region of Thailand into five groups according to landscape. This included the coastal area, urban area, upper alluvial area, lower alluvial area and mountainous area (Figure 1). Thereafter, one province was selected in each group until there were 5 provinces that represented the 5 landscapes. This was done using generating random numbers using a Random Generator programmed, a web-based application that is freely available at link: https://random.thaiware.com. The results of random provinces for study were Samut Songkram (coastal area representative), Bangkok (urban area representative), Phranakhon Si Ayutthaya (Lower alluvial area representative), Nakhon Sawan (upper alluvial area representative) and Sukhothai (mountainous area representative)"(Table 1). After these three sites had been selected for the collection of flies to represent each province, the criteria were set. These were areas where people lived in high density and the area of collection could include a dump site or afresh food market (Figure 2).

\section{Fly collections and identification}

The trap for the fly collection in this study was modified from a prototype trap $(30 \times 30 \times 50 \mathrm{~cm})$ from the World Health Organization (1991) and the bait was pork liver, which was left for one night. We also used insect nets to collect flies in tandem with the traps. Fly collections were performed in July 2018 from $06.00 \mathrm{~h}-18.00 \mathrm{~h}(12$ hours) once per collected site (4 traps per site). Fly traps at each site were placed near the garbage dump, which has a large population of flies and facilitated the ease of capture collection. After $18.00 \mathrm{~h}$, collected flies were removed from traps and were killed using dry ice $\left(\mathrm{CO}_{2}\right)$ with 15minute infusions. All the flies were transported to the laboratory at the College of Allied Health Sciences, Suan Sunandha Rajabhat University, Samut Songkhram Provincial Education Center, Thailand. Then, specimens
Table 1. Geo-referenced locality of study site, the central region of Thailand

\begin{tabular}{|c|c|c|c|c|}
\hline $\begin{array}{l}\text { Types of } \\
\text { Landscape }\end{array}$ & Latitude & Longitude & $\begin{array}{c}\text { Altitude } \\
\text { (ft.) }\end{array}$ & $\begin{array}{c}\begin{array}{c}\text { Distance } \\
\text { from sea } \\
(\mathbf{k m})\end{array} \\
\end{array}$ \\
\hline \multicolumn{5}{|l|}{ Coastal area } \\
\hline Site1 & $13^{\circ} 23^{\prime} 49.1^{\circ} \mathrm{N}$ & $100^{\circ} 02^{\prime} 22.0^{\circ} \mathrm{E}$ & 10 & 0.11 \\
\hline Site2 & $13^{\circ} 21^{\prime} 43.1^{\circ} \mathrm{N}$ & $100^{\circ} 01^{\prime} 22.5^{\circ} \mathrm{E}$ & 16 & 0.17 \\
\hline Site3 & $13^{\circ} 22^{\prime} 54.9^{\circ} \mathrm{N}$ & $99^{\circ} 58^{\prime} 49.1^{\circ} \mathrm{E}$ & 23 & 4.10 \\
\hline \multicolumn{5}{|l|}{ Urban area } \\
\hline Site1 & $13^{\circ} 43^{\prime} 52.5^{\circ} \mathrm{N}$ & $100^{\circ} 32^{\prime} 29.5^{\circ} \mathrm{E}$ & 26 & 27.07 \\
\hline Site2 & $13^{\circ} 48^{\prime} 15.9^{\circ} \mathrm{N}$ & $100^{\circ} 32^{\prime} 59.6^{\circ} \mathrm{E}$ & 16 & 34.97 \\
\hline Site3 & $13^{\circ} 45^{\prime} 44.3^{\circ} \mathrm{N}$ & $100^{\circ} 32^{\prime} 28.0^{\circ} \mathrm{E}$ & 30 & 32.99 \\
\hline \multicolumn{5}{|c|}{ Lower alluvial } \\
\hline Site1 & $14^{\circ} 21^{\prime} 33.438^{\circ} \mathrm{N}$ & $14^{\circ} 21^{\prime} 33.438^{\circ} \mathrm{N}$ & 13 & 95.72 \\
\hline Site2 & $14^{\circ} 20^{\prime} 40.647^{\circ} \mathrm{N}$ & $100^{\circ} 35^{\prime} 29.264^{\prime \prime} \mathrm{E}$ & E 30 & 94.23 \\
\hline Site3 & $14^{\circ} 22^{\prime} 16.1^{\circ} \mathrm{N}$ & $100^{\circ} 36^{\prime} 27.1^{\circ} \mathrm{E}$ & 26 & 100.58 \\
\hline \multicolumn{5}{|c|}{ Upper alluvial area } \\
\hline Site 1 & $15^{\circ} 42^{\prime} 01.0^{\circ} \mathrm{N}$ & $100^{\circ} 07^{\prime} 35.5^{\circ} \mathrm{E}$ & 85 & 245.41 \\
\hline Site2 & $15^{\circ} 42^{\prime} 12.9^{\circ} \mathrm{N}$ & $100^{\circ} 08^{\prime} 30.7^{\circ} \mathrm{E}$ & 115 & 244.17 \\
\hline Site3 & $15^{\circ} 39^{\prime} 10.3^{\circ} \mathrm{N}$ & $100^{\circ} 17^{\prime} 58.2^{\circ} \mathrm{E}$ & 85 & 243.07 \\
\hline \multicolumn{5}{|c|}{ Mountainous area } \\
\hline Site1 & $17^{\circ} 1^{\prime} 06.415^{\circ} \mathrm{N}$ & $99^{\circ} 42^{\prime} 35.256^{\circ} \mathrm{E}$ & 207 & 390.59 \\
\hline Site2 & $17^{\circ} 01^{\prime} 03.7^{\circ} \mathrm{N}$ & $99^{\circ} 42^{\prime} 13.3^{\circ} \mathrm{E}$ & 203 & 397.90 \\
\hline Site3 & $16^{\circ} 52^{\prime} 38.9^{\circ} \mathrm{N}$ & $99^{\circ} 41^{\prime} 32.6^{\circ} \mathrm{E}$ & 653 & 395.88 \\
\hline
\end{tabular}

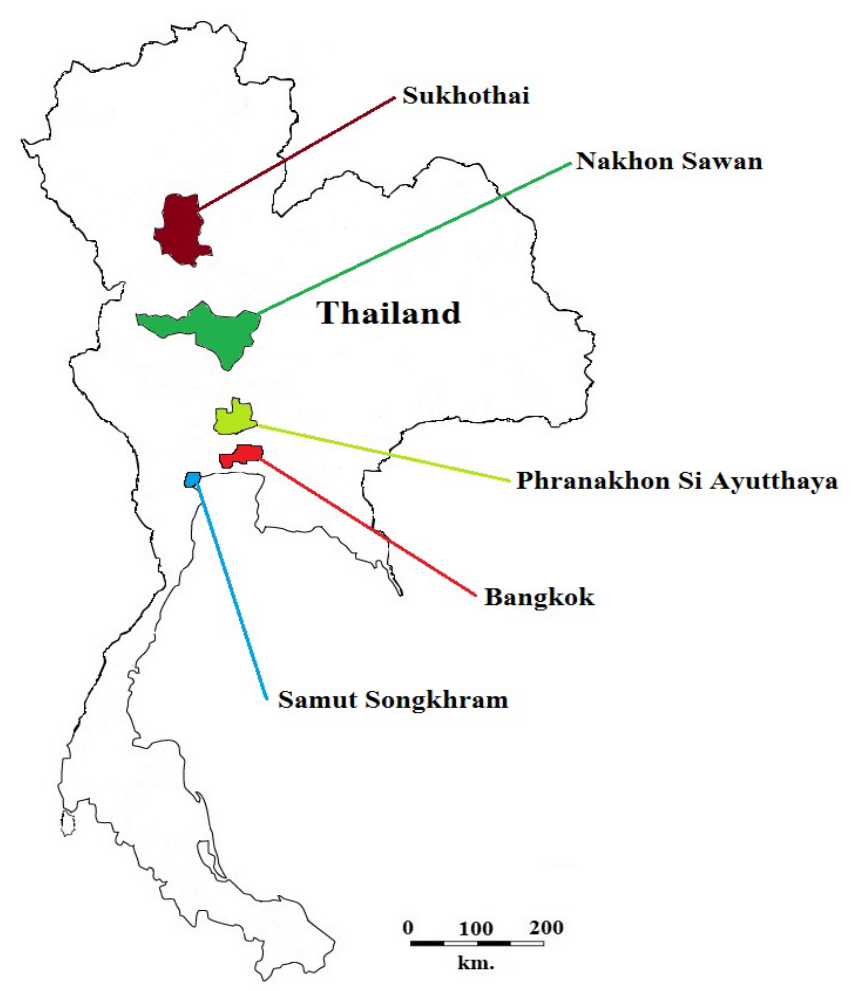

Figure 1. Five study areas in the central region of Thailand, indicating Samut Songkram (coastal area), Bangkok (urban area), Phranakhon Si Ayutthaya (lower alluvial area), Nakhon Sawan (upper alluvial area) and Sukhothai (mountainous area) 


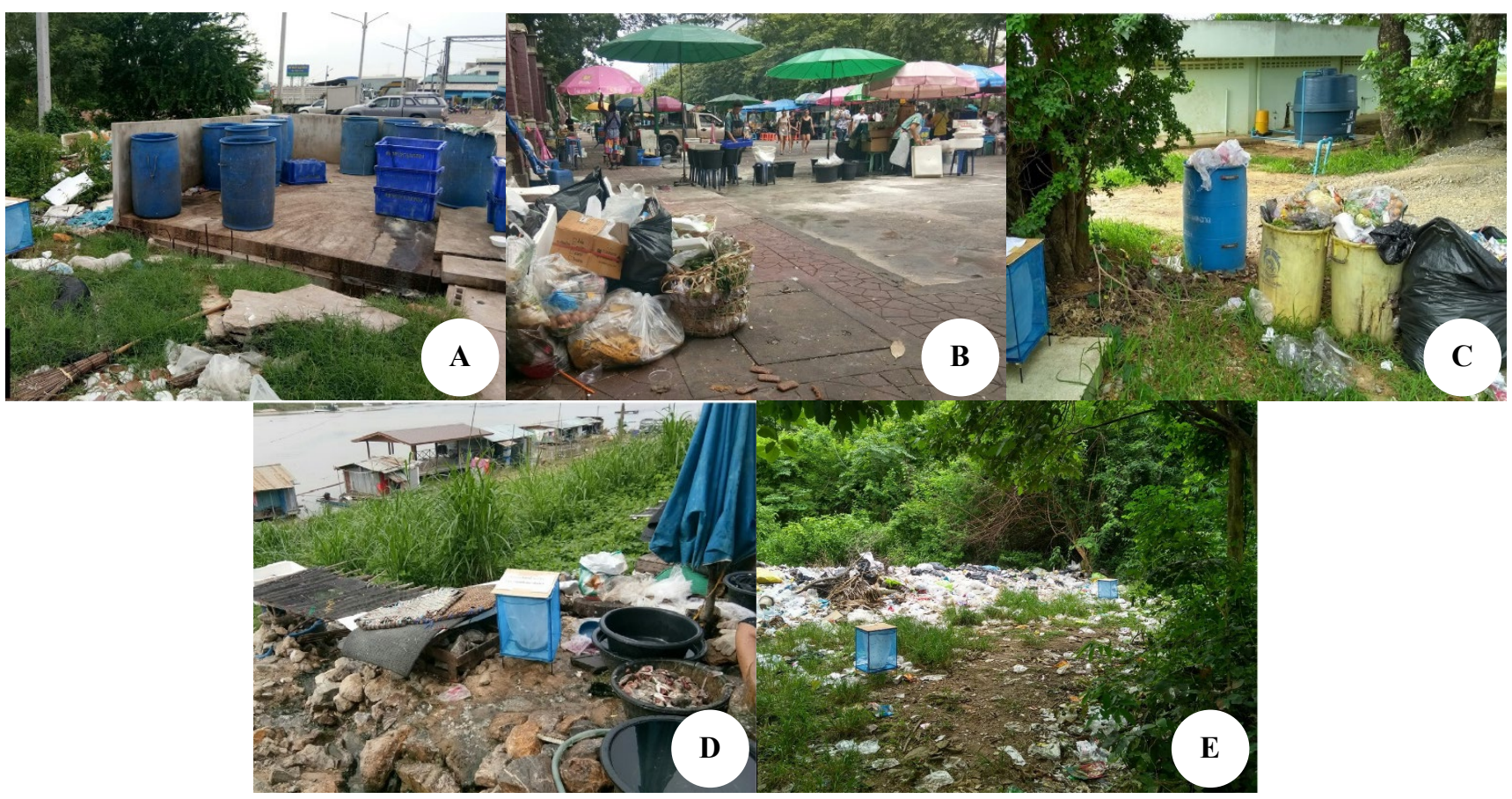

Figure 2. General topography of specimen collection sites in each landscape: A. Coastal area, B. Urban area, C. Lower alluvial area, D. Upper alluvial area, E. Mountainous area

were identified based on morphological character and using the taxonomic keys of Kurahashi and Chaiwong (2013), Tumrasvin and Shinonaga (1978), Carvalho and MelloPatiu (2008). Subsequently, photographs were taken with the program called NIS-Elements Documentation, under a Nikon SMZ745T stereo-microscope (Nikon Corp., Tokyo, Japan).

\section{Data analysis}

The results of the abundance and distribution of flies in the central region of Thailand are presented by percentage.

\section{RESULTS AND DISCUSSION}

In July 2018 (one day per collected site), we used 4 fly traps per site in five provinces in the central region, Thailand to collect 3872 adult flies belonging to 4 subfamilies and 6 genera within 9 species. This included Achoetandrus rufifacies (Macquart, 1843), A. villeneuvi (Patton, 1922), Chrysomya megacephala (Fabricius, 1794), C. nigripes (Aubertin, 1932), Hemipygiopsis ligurriens (Wiedemann, 1830), Lucilia cuprina (Wiedemann, 1830), L. papuensis (Macquart, 1842), Musca domestica (Linnaeus, 1758) and Sacrophaga spp. (Table 2, Figures 3-4).

With this survey, we studied the abundance and distribution of flies in each landscape in the central region of Thailand and found the highest number of flies were in mountainous area, followed by coastal areas, upper alluvial area, urban area, and lower alluvial area, respectively. Based on all the study areas in the central region, it was found that $C$. megacephala was the predominant species, with 2953 adult flies captured, followed by $M$. domestica $(\mathrm{n}=563)$, A. rufifacies $(\mathrm{n}=177)$ and Sacrophaga spp. $(\mathrm{n}=$ 137), respectively. In addition, the four species of flies collected in this study were $L$. cuprina $(\mathrm{n}=28)$, A. villeneuvi $(\mathrm{n}=2), C$. nigripes $(\mathrm{n}=2)$ and H. ligurriens $(\mathrm{n}=2)$ (Table 2).

The results of abundance and distribution of flies were divided according to characteristics of the landscape with Sukhothai Province, as a mountainous area, found to include 7 species and a total of 1772 adult flies. The most abundant species was the $C$. megacephala accounting for $78.49 \% \quad(\mathrm{n}=1391)$ and the lowest species were $A$. villeneuvi and $H$. ligurriens, accounting for $0.11 \%(\mathrm{n}=2)$. Samut Songkram Province, as a coastal area, had 6 species and a total of 650 adult flies, the most abundant species being the $C$. megacephala, accounting for $69.69 \%(\mathrm{n}=453)$, while the lowest species was $C$. nigripes and $L$. cuprina $0.30 \%(\mathrm{n}=2)$. The upper alluvial area or Nakhon Sawan Province had 6 species and a total of 634 adult flies. $C$. megacephala was the most abundant species, accounting for $80.59 \%(\mathrm{n}=511)$ and the lowest was A. rufifacies $0.31 \%(\mathrm{n}=2)$. Next, Bangkok's urban area was found to have only 3 species and a total of 624 adult flies, with the most abundant species being $C$. megacephala, which accounted for $81.57 \%(\mathrm{n}=509)$ and the lowest was Sacrophaga spp. at $1.92 \%(\mathrm{n}=12)$. Finally, Phranakhon $\mathrm{Si}$ Ayutthaya, which was the lower alluvial area, was found to have 5 adult fly species (a total of 192 flies). Chrysomya megacephala was the most abundant species, accounting for $46.35 \%(n=89)$ and the lowest was Sacrophaga spp. $2.60 \%(n=11)$, respectively (Table 2$)$. 
Table 2. Frequency of collected flies in the central region of Thailand

\begin{tabular}{|c|c|c|c|c|c|c|}
\hline \multirow[b]{2}{*}{ Species of flies } & \multicolumn{5}{|c|}{ Percentage of occurrence of flies species } & \multirow[b]{2}{*}{ Total } \\
\hline & Coastal area & $\begin{array}{l}\text { Urban } \\
\text { area }\end{array}$ & $\begin{array}{c}\text { Lower alluvial } \\
\text { area }\end{array}$ & $\begin{array}{c}\text { Upper alluvial } \\
\text { area }\end{array}$ & $\begin{array}{c}\text { Mountainous } \\
\text { area }\end{array}$ & \\
\hline $\begin{array}{l}\text { Subfamily: Chrysomyinae } \\
\text { A. rufifacies (Macquart, 1843) }\end{array}$ & $0.61 \%(4)$ & 0 & 0 & $0.31 \%(2)$ & $9.65 \%(171)$ & 177 \\
\hline $\begin{array}{l}\text { A. villeneuvi (Patton, 1922) } \\
\text { C. megacephala (Fabricius, 1794) } \\
\text { C. nigripes (Aubertin, 1932) }\end{array}$ & $\begin{array}{c}0 \\
69.69 \%(53) \\
0.30 \%(2)\end{array}$ & $\begin{array}{c}0 \\
81.57 \%(509) \\
0\end{array}$ & $\begin{array}{c}0 \\
46.35 \%(89) \\
0\end{array}$ & $\begin{array}{c}0 \\
80.59 \%(511) \\
0\end{array}$ & $\begin{array}{c}0.11 \%(2) \\
78.49 \%(1391) \\
0\end{array}$ & $\begin{array}{c}2 \\
2953 \\
2\end{array}$ \\
\hline $\begin{array}{l}\text { Subfamily: Luciliinae } \\
\text { H. ligurriens (Wiedemann, 1830) } \\
\text { L. cuprina (Wiedemann, 1830) }\end{array}$ & $\begin{array}{c}0 \\
0.30(2)\end{array}$ & $\begin{array}{l}0 \\
0\end{array}$ & $\begin{array}{c}0 \\
8.85 \%(17)\end{array}$ & $\begin{array}{c}0 \\
0.63 \%(4)\end{array}$ & $\begin{array}{l}0.11 \%(2) \\
0.28 \%(5)\end{array}$ & $\begin{array}{c}2 \\
28\end{array}$ \\
\hline L. papuensis (Macquart, 1842) & 0 & 0 & $2.60 \%(5)$ & $0.47 \%(3)$ & 0 & 8 \\
\hline $\begin{array}{l}\text { Subfamily: Muscindae } \\
\text { M. domestica (Linnaeus, 1758) }\end{array}$ & $26.1 \% 170)$ & $16.50 \%(103)$ & $36.46 \%(70)$ & $14.66 \%(93)$ & $7.16 \%(127)$ & 563 \\
\hline $\begin{array}{l}\text { Subfamily: Sarcophagidae } \\
\text { Sacrophaga spp. } \\
\text { Total }\end{array}$ & $\begin{array}{c}2.9 \%(19) \\
100 \%(650)\end{array}$ & $\begin{array}{l}1.92 \%(12) \\
100 \%(624)\end{array}$ & $\begin{array}{l}5.72 \%(11) \\
100 \%(192)\end{array}$ & $\begin{array}{l}3.31 \%(21) \\
100 \%(634)\end{array}$ & $\begin{array}{c}4.17 \%(74) \\
100 \%(1772)\end{array}$ & $\begin{array}{c}137 \\
3872\end{array}$ \\
\hline
\end{tabular}

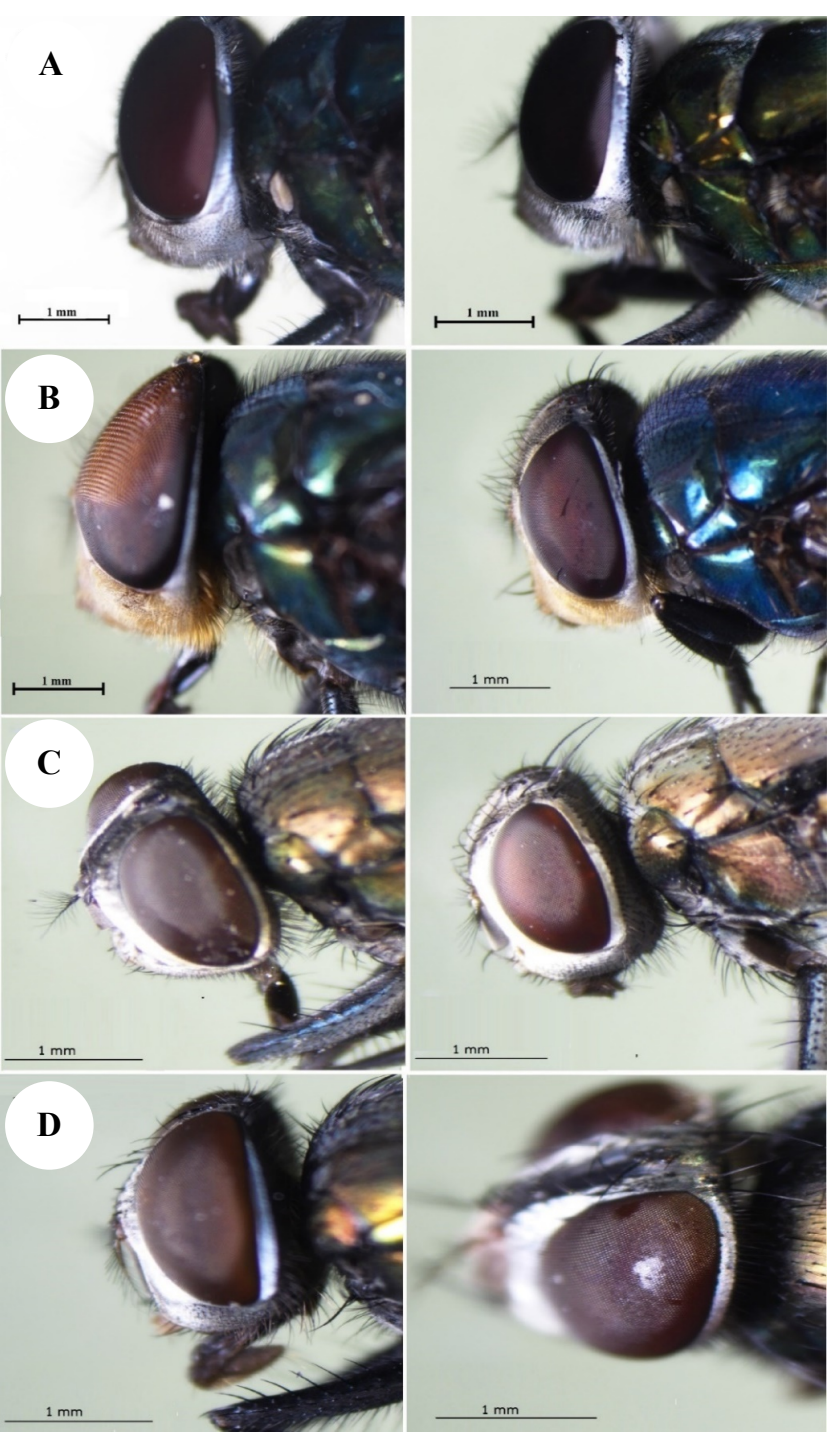

Figure 3. Lateral views of the medically important blow flies: A. $A$. rufifacies (left: male and right: female), B. C. megacephala (left: male and right: female), C. L. cuprina (left: male and right: female), D. L. papuensis (left: male and right: female)

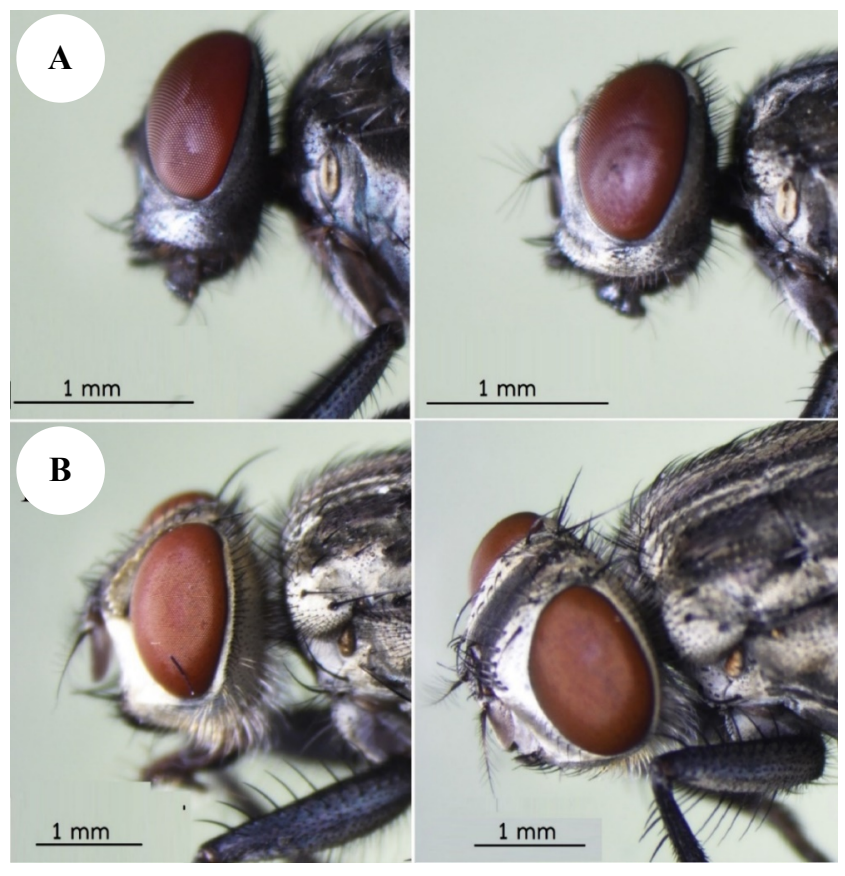

Figure 4. Lateral views of medically important house fly and flesh fly: A. M. domestica (left: male and right: female), B. Sacrophaga spp. (left: male and right: female)

\section{Discussion}

This research was the field one that aimed at studying the checklist of flies in the central region of Thailand. In this study, we found 9 species of medically important flies, belonging 6 genera. These findings were consistent with previous research-conducted surveys regarding medically important flies in Thailand (Tumrasvin and Shinonaga 1978; Tumrasvin et al. 1979; Kurahashi and Chaiwong 2013).

Although nine species of non-biting flies were found in the central region, each area had a different species of flies, depending on the landscape. This was consistent with the research done by (Bunchu et al. 2012) which was 
conducted to find the occurrence of blowfly species in the Phitsanulok province, Thailand. The province was divided into 4 areas according to types of landscape, including agricultural, mountainous, forest and residential and it was found that each area had different species and numbers of blowflies. For instance, species such as C. pinguis (Monum et al. 2017) and C. thanomthini (Tumrasvin et al. 1977) were only found in mountainous areas. The influence of the landscape on the flies has an effect on the number and appropriate habitat on each species and each environment has specific properties ideal for the localized species (Junqueira et al. 2017). Our results of specimen collection in July 2018 showed that the mountainous area had the highest number of fly species (seven species) and the urban area had the lowest number of fly species (three species). This result was consistent with the previous research performed by Bunchu et al. (2012) which surveyed blow flies in July and found the highest number of flies species in mountainous area (15 species) and the lowest number in urban area (three species) due to environmental suitability influences species-specific abundance patterns of flies. $\square$

Each species of flies has a different habitat, which was dependent on the environment and ecology. Usually, $A$. rufifacies was found with the second highest number of blowfly species, with C. megacephala as the predominant one. This corresponded to our results. Indeed, blowfly $A$. rufifacies is classified as a very important medical fly (Getachew et al. 2007). Previous research reports have found that $A$. rufifacies were the most significant carriers of the helminths and protozoan parasites when compared with the other flies (Getachew et al. 2007). Chrysomya megacephala was the predominant species in the central region of Thailand. This is a highly important vector and these flies can be found throughout nature settings, such as Pelotas, Brazil (Bunchu et al. 2012). In addition, $C$. megacephala had more potential to carry pathogens than M. domestica (Monzon et al. 1991). In this study, we found $A$. villeneuvi and $H$. ligurriens only in mountainous areas, a fact which matched a research report regarding $A$. villeneuvi being only found in forested and mountainous areas at high altitude. However, $H$. ligurriens is predominantly in the lowlands that are 45-60 meters above sea level (Bunchu et al. 2012). However, It can be found in sparse numbers in other areas that are not very high (Tumrasvin et al. 1979). Occurrences of blowfly $C$. nigripes in coastal areas of Samut Songkram province, Thailand in this survey were first recorded due to this species being predominantly collected in the specific high altitude areas (Bunchu et al. 2012; Phasuk et al. 2013). Currently, C. nigripes is considered a forensically important blowfly species (Greenberg 1991). For Lucilia Genera, we were only able to find small numbers, including $L$. cuprina and L. papuensis. The results for Lucilia spp. showed that it could be found more in alluvial areas than other landscapes. The blowfly $L$. cuprina is considered to play an important role in the medical vector, due to particular properties such as parasite eggs, protozoa cysts and other pathogens (Bunchu et al. 2012), while, M. domestica and Sacrophaga spp. were found throughout the central region of Thailand. One reason for M. domestica being found in all areas was due to its being able to easily adapt to the environment (Diclaro et al. 2012).

The result of this study has shown the distribution of flies, which is important information for identifying diarrhea vector control. In addition to this research, it was also revealed that there was a new record of flies, $C$. nigripes, in coastal areas of Samut Songkram province, Thailand.

In conclusion, the present study revealed the abundance and distribution of medically important flies in the central region of Thailand, where 9 species of important medical flies were found. In each landscape, there were different numbers and species of flies. These results are useful, basic medical entomological information for planning the control of diarrhea vectors.

\section{ACKNOWLEDGEMENTS}

The authors would like to acknowledge the College of Allied Health Sciences, Suan Sunandha Rajabhat University, Thailand.

\section{REFERENCES}

Akbarzadeh K, Saghafipour A, Jesri N, Karami-Jooshin M, Arzamani K, Hazratian T, Kordshouli RS, Afshar AA. 2018. Spatial Distribution of Necrophagous Flies of Infraorder Muscomorpha in Iran Using Geographical Information System. J Med Entomol 55: 1071-1085. DOI.org//10.1093/jme/tjy098

Barreiro C, Albano H, Silva J, Teixeira P. 2013. Role of flies as vectors of foodborne pathogens in rural areas. SRN Microbiol. DOI: 10.1155/2013/718780.

Bunchu N, Sukontason K, Sanit S, Chidburee P, Kurahashi H, Sukontason KL. 2012. Occurrence of blowfly species (Diptera: Calliphoridae) in Phitsanulok Province, Northern Thailand. Trop Biomed 29: 532-543.

Carvalho CJB, Mello-Patiu CA. 2008. Key to the adults of the most common forensic species of Diptera in South America. Rev Bras Entomol. DOI: 10.1590/S0085-56262008000300012.

Diclaro JW, Cohnstaedt LW, Pereira RM, Allan SA, Koehler PG. 2012. Behavioral and physiological response of Musca domestica to colored visual targets. J Med Entomol. DOI: 10.1603/ME10257.

Division of Control of Tropical Diseases, World Health Organization. 1991. The Housefly: training and information guide. World Health Organization, Geneva.

El-Sherbini GT, Gneidy MR. 2012. Cockroaches and flies in mechanical transmission of medically important parasites in Khaldyia village, ElFayoum, Governorate, Egypt. J Egypt Soc Parasitol. DOI: $10.12816 / 0006304$.

Fetene T, Worku N. 2009. Public health importance of non-biting cyclorrhaphan flies. Trans R Soc Trop Med Hyg 103: 187-191.

Francesconi F, Lupi O. 2012. Myiasis. Clin Microbiol Rev. DOI: 10.1128/CMR.00010-11.

Getachew S, Gebre-Michael T, Erko B, Balkew M, Medhin G. 2007. Nonbiting cyclorrhaphan flies (Diptera) as carriers of intestinal human parasites in slum areas of Addis Ababa, Ethiopia. Acta Trop. DOI: 10.1016/j.actatropica.2007.06.005.

Graczyk TK, Knight R, Tamang L. 2005. Mechanical transmission of human protozoan parasites by insects. Clin Microbiol Rev. DOI: 10.1128/CMR.18.1.128-132.2005.

Greenberg B. 1971. Flies and Disease, Vol I: Ecology, classification, and biotic associations. Princeton Univ Press, USA.

Greenberg B. 1991. Flies as forensic indicators. J Med Entomol. DOI: 10.1093/jmedent/28.5.565.

Joseph I, Mathew D, Sathyan P, Vargheese G. 2011. The use of insects in forensic investigations: An overview on the scope of forensic entomology. J Forensic Dent Sci. DOI: 10.4103/0975-1475.92154. 
Junqueira ACM, Ratan A, Acerbi E, Drautz-Moses DI, Premkrishnan BNV, Costea PI, Schuster SC. 2017. The microbiomes of blowflies and houseflies as bacterial transmission reservoirs. Sci Rep. DOI: 10.1038/s41598-017-16353-x. $\square$

Khalil K, Lindblom GB, Mazhar K, Kaijser B. 1994. Flies and water as reservoirs for bacterial enteropathogens in urban and rural areas in and around Lahore, Pakistan. Epidemiol Infect. DOI: $10.1017 / \mathrm{S} 0950268800068448$. $\square$

Kurahashi H, Chaiwong T. 2013. Keys to the flesh flies of Thailand, with description of a new species of Robineauella enderlein (Diptera: Sarcophagidae). J Entomol Zool Stud 64: 83-101.

Milligan SR, Holt WV, Lloyd R. 2009. Impacts of climate change and environmental factors on reproduction and development in wildlife. Philos Trans R Soc Lond B Biol Sci 364: 3313-3319.

Ministry of Public Health, Thailand. 2017. Annual report. Bureau of vector-borne disease, Bankok, Thailand.

Monum T, Sukontason KL, Sribanditmongkol P, Sukontason K, Samerjai C, Limsopatham K, Wannasan A. 2017. Forensically importan blowflies Chrysomya pinguis, C. villeneuvi, and Lucilia porphyrina (Diptera: Calliphoridae) in a case of human remains in Thailand. Korean J Parasitol. DOI: 10.3347/kjp.2017.55.1.71.

Monzon RB, Sanchez AR, Tadiaman BM, Najos OA, Valencia EG, de Rueda RR, Ventura JV. 1991. A comparison of the role of Musca domestica (Linnaeus) and Chrysomya megacephala (Fabricius) as mechanical vectors of helminthic parasites in a typical slum area of metropolitan Manila. T Southeast Asian J Trop Med Public Health 22: $222-228$.

Nwe Oo K, Sebastian AA, Aye T. 1989. Carriage of enteric bacterial pathogens by house flies in Yangon, Myanmar. J Diarrhoeal Dis Res 7: $81-84$.
Nyarango RM, Aloo PA, Kabiru EW, Nyanchongi BO. 2008. The risk of pathogenic intestinal parasite infections in Kisii Municipality, Kenya. BMC Public Health. DOI: 10.1186/1471-2458-8-237.

Phasuk J, Tharawoot T, Chanpaisaeng J. 2013. Seasonal abundance of blowflies (Diptera: Calliphoridae) in three urban parks of Bangkok, Thailand. Kasetsart J 47: 828-834.

Phoku JZ, Barnard TG, Potgieter N, Dutton MF. 2014. Fungi in housefly (Musca domestica) as a disease risk indicator-a case study in South Africa. Acta Trop. DOI: 10.1016/j.actatropica.2014.08.019.

Service M. 2008. Medical entomology for students, fourth edition. Cambridge University Press, Cambridge, United Kingdom.

Sukontason KL, Bunchoo M, Khantawa B, Piangjai S, Rongsriyam Y, Sukontason K. 2007. Comparison between Musca domestica and Chrysomya megacephala as carriers of bacteria in northern Thailand. Southeast Asian J Trop Med Public Health 1: 38-44.

Tumrasvin W, Kurahashi H, Kano R. 1977. Studies on medically important flies in Thailand II, Record of four species of Lucilia robineau-desvoidy (Diptera: Calliphoridae). Bull Tokyo Med Dent Univ 24: 1-8.

Tumrasvin W, Kurahashi H, Kano R. 1979. Studies on medically important flies in Thailand VII, Report on 42 species of calliphorid flies including the taxonomic keys (Diptera: Calliphoridae). Bull Tokyo Med Dent Univ 25: 201-227.

Tumrasvin W, Shinonaga S. 1978. Studies on medically important flies in Thailand. V. On 32 species belonging to the subfamilies Muscinae and Stomoxyinae including the taxonomic keys (Diptera: Muscidae). Bull Tokyo Med Dent Univ 2: 77-81. 